\title{
Income Generating Activities of Rural Women: A Tool for Poverty Alleviation and Decision-making
}

\author{
Pooja Jena ${ }^{1}$, Manoher Saryam ${ }^{2 *}$, Bijay Kumar Mohanty ${ }^{3}$ and A.K. Prahraj ${ }^{4}$ \\ ${ }^{1}$ Department of Extension Education, Bihar Agricultural University, Sabour, Bihar, India \\ ${ }^{2}$ Department of Extension Education, Institute of Agricultural Sciences, Banaras Hindu University, Varanasi, Uttar Pradesh, India \\ ${ }^{3}$ Institute of Agricultural Sciences, Siksha 'O' Anusandhan Unuversity, Bhubaneswar, Odisha, India \\ ${ }^{4}$ IGNOU Centre, Rourkela, Odisha, India
}

*Corresponding author: manohar.saryam@gmail.com (ORCID ID: 0000-0002-7679-4420)

Received: 14-03-2021

Revised: 20-05-2021

Accepted: 10-06-2021

\begin{abstract}
The present paper attempts to examine the income generating activities among rural women in Chhindwara district of Madhya Pradesh in the year of 2019-20. The study was conducted in 06 villages located at bichhua block of Chhindwara district. Data for the study was collected from a sample of 100 respondents. The study found that higher percentage of the rural women (52\%) belonged to young age group, (30\%) of the rural women were in the category of high school, (50\%) were marginal rural women, (50\%) of rural women had small family size having up to 5 members, (55\%) rural women had nuclear family system, (45.00\%) of rural women were doing work as agriculture, (45.00\%) had annual income ₹ 15,001 to 20,000, (70\%) of the respondents had high training need while about $20 \%$ of them had medium training need for income generation activities of rural women, (85\%) training needs were in nursery establishment and the rest three components namely vegetable production, animal husbandry and poultry activities claimed more or less similar proportion of training needs. The relationship between independent variables and extent of training needs in conducting Income Generating Activities was significant with age, education, landholding, type of family, occupation and annual income.
\end{abstract}

\section{HIGHLIGHTS}

(0 This shows the profile of rural women who engaged in income-generating activities in agriculture and allied fields.

0 Decision-making is the critical factor for women empowerment.

( Vocational Training is the critical factor for decision-making about farming and livelihood activity.

Keywords: Income, rural women, empowerment, agriculture, farming and training needs, poverty alleviation, capacity building and strengthening

Farming is more than just another avenue of employment for farmers in developing countries. It is a way of life. In fact, for most subsistence farmers, agricultural activity is enmeshed in their very ethos of life, which is why the structural transformation of an economy from traditional agriculture to modern industrialization is a

How to cite this article: Jena, P., Saryam, M., Mohanty, B.K. and Prahraj, A.K. (2021). Income Generating Activities of Rural Women: A Tool for Poverty Alleviation and Decision-making. Int. J. Soc. Sci., 10(02): 163-171.

Source of Support: None; Conflict of Interest: None (क) 
lot more challenging than it seems at the outset. In the literature on peasants, explanations of peasant behavior have often been sought in the specificity of their motives, postulating that peasants are not utility maximizers, by difference with other households, but are motivated instead by the satisfaction of their needs or by the desire to ensure 'simple production' Vergopoulos, (1978). While it may be true that subsistence farmers in developing countries aspire towards income growth and material well-being, food self-sufficiency and income security may be more compelling and immediately pertinent issues for them.

In the Indian socio-economic context, income generation assumes great significance for women, especially rural women. The fast-changing time has brought many new interests and responsibilities into women's orbit and has altered the pattern of home life to a great extent both in urban and rural setup. The ever-increasing price line has made it difficult to maintain a family economically sound. Thus, the participation of women in income generating activities is indispensable not only for the survival of individual families but for the maintenance of the wider socio-economic system. Though women are entering in various fields yet they have low participation in the workforce due to inadequacy of skills, illiteracy, restricted mobility, and lack of individual status Chari, (1983). Women are employed mainly in the unorganized sector Mehta and Sethi, (1977). In addition to this, voluntary organizations, as well as Government organizations, engage women in the production of different items.

Realizing that women can supplement the family income, it was thought appropriate to know the different -generating activities performed by rural women; and determine their level of satisfaction and dissatisfaction.

The low status of women in large segments of Indian Society cannot be raised without the opening up of opportunities of independent employment and income further. Economic independence makes women conscious of their rights. Working outside the home and coming into contact with other people have broadened their outlook and mental horizon. A woman was recently considered unfit for roles other than that of housewife, nurse, primary school teacher, sales girl, telephone operator, stenographer, and receptionist. The image of women in society is fast changing. However, it isn't easy to define or describe clearly the changing shape of the image. One thing is clear that women are entering the labor force in a large number. For many women, work is regarded as an unfortunate economic necessity. It is seen as very much a secondary activity to running a home and looking after children. The real change and development of civilization largely is the result of trade, commerce, and industrialization. In this development, the human resource in general and entrepreneur, in particular, plays a pivotal role.

The present status of women is an essential factor for the overall development of a country. The total development of India will undoubtedly be hampered if the status of women, constituting about 50 percent of the country's population, remains as low as it is today. They face discrimination in both their public and private lives. Despite the equality in the male and female ratio in Bangladesh, the importance and potentialities of women have been disregarded in socio-economic development. Women were the indicators of domestic activities in the history of humankind. Recently their participation of income-generating activities is being increased. It is widely perceived that women in India are getting empowered by attaining more access to financial activities.

Empowerment means giving power and authority to women. It is a multi-dimensional process through which women enable themselves to realize their full identity and power in all spheres of life. It consists of greater access to knowledge and resources, greater autonomy in decision making to enable them to have a more remarkable ability to plan their lives. The term "empowerment" means to give somebody the power or authority to do something (Oxford Dictionary). In undertaken with the following specific objectives such as know the socio-economic profile of rural women, Training need of the rural women for increasing the annual family income and participation, Relationships between the selected characteristics of the rural women and their extent of training needs and Suggestion for improving the Income Generating Activities among rural women. 


\section{METHODS}

The study was carried out in the Chhindwara district of Madhya Pradesh. Chhindwara district comprises of 12 tehsils viz. Amarwada, Chhindwara, harrai, jamai, Mukhed, tamia, umreth, Chourai, Parasia, Bichhua, Sausar, and Pandurna. The Bichhua block was selected purposively for the study because it's convenient for the study and familiar with the respondents. A list of villages of Bichhua block prepared with the help of NRLM officer and out of which 6 villages were selected randomly, namely silota kala, Moya, Surangi, Dokli, and Raiyatwari. A list of rural women of each selected village were prepared with the help of NRLM officer. Rural women were selected by using a simple random sampling method. The total number of selected rural women was 100 .

Data collected from farmers with the help of face to face interaction Personal interview of each individual farmers. This study was based on primary data, which was collected with the help of well structured \& pre tested interview schedule. The following statistical tests and measures are used for the analysis of the data. Frequency, Percentage, Category, Arithmetic Mean, Standard Deviation, and Correlation.

\section{RESULTS AND DISCUSSION}

\section{Socio-Economic Profile of Rural Women}

It relates to the respondents' information in connection to personal socio-psycho characteristics viz., age, education, landholding, size of family, type of family, occupation, annual income.

Table 1: Distribution of Rural women according to their age $(\mathrm{n}=100)$

\begin{tabular}{llll}
\hline $\begin{array}{l}\text { S1. } \\
\text { No. }\end{array}$ & Categories & $\begin{array}{l}\text { No. of } \\
\text { beneficiaries }\end{array}$ & Percentage \\
\hline 1 & Young (Upto 35) & 52 & 52 \\
2 & Middle (36 to 50) & 30 & 30 \\
3 & Old (Above 50) & 28 & 28 \\
\hline Total & & $\mathbf{1 0 0}$ & $\mathbf{1 0 0}$ \\
\hline
\end{tabular}

Table 1 revealed that out of the total rural women, a higher percentage i.e. 52 percent belonged to the young age group, 30 percent middle age group, while only 28 percent belonged to old age group.

Thus, it is evident that a higher percentage of the rural women $(52 \%)$ belonged to the young age group. The findings are in line with the findings of Dhawan (2002), Gurjar (2002), Baghel (2003), Meshram (2003), and Tripathi (2008).

Table 2: Distribution of Rural women according to their education level $(n=100)$

\begin{tabular}{llll}
\hline S1. No. & Education level & $\begin{array}{l}\text { No. of } \\
\text { beneficiaries }\end{array}$ & Percentage \\
\hline 1 & Primary & 25 & 25 \\
2 & Middle & 20 & 20 \\
3 & High School & 30 & 30 \\
4 & Higher Secondary & 20 & 20 \\
5 & Above & 05 & 05 \\
\hline & Total & $\mathbf{1 0 0}$ & $\mathbf{1 0 0}$ \\
\hline
\end{tabular}

Table 2 revealed that out of the total rural women, 25 percent were educated up to primary school, 20 percent educated up to middle school, 30 percent educated up to high school, 20 percent educated up to higher secondary, and only 05 percent educated up to graduation level.

Thus, it can be concluded that a higher percentage (30\%) of the rural women were in the category of high school. The findings are in line with the findings of Yarpude (2000), Lyaqet (2001), Meshram (2003), and Shakya (2007).

Table 3: Distribution of Rural women according to their size of landholding $(\mathrm{n}=100)$

\begin{tabular}{llll}
\hline $\begin{array}{l}\text { S1. } \\
\text { No. }\end{array}$ & Land Holding & $\begin{array}{l}\text { No. of } \\
\text { beneficiaries }\end{array}$ & Percentage \\
\hline 1 & Marginal farmers (Upto 01 ha.) & 50 & 58.75 \\
2 & Small famer (1.1 to 2.0 ha) & 30 & 28.75 \\
3 & Medium farmers (4.1 to 10 ha ) & 20 & 12.5 \\
\hline & Total & $\mathbf{1 0 0}$ & $\mathbf{1 0 0}$ \\
\hline
\end{tabular}

Data presented in Table 3 revealed that out of total rural women, a higher percentage i.e., 50 percent were marginal landholding of rural women, 30 percent were small rural women. In comparison, only 20 percent were medium rural women. Thus, it is evident that the 


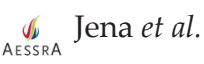

majority of the rural women (50\%) were marginal rural women.

Table 4: Distribution of Rural women according to their size of family $n=100$

\begin{tabular}{llll}
\hline S1. No. & Categories & $\begin{array}{l}\text { No. of } \\
\text { beneficiaries }\end{array}$ & Percentage \\
\hline 1 & Small (Up to 5 members) & 25 & 25 \\
2 & Medium (6 to 8 members) & 50 & 50 \\
3 & Large (Above 8) & 35 & 35 \\
\hline & Total & $\mathbf{1 0 0}$ & $\mathbf{1 0 0}$ \\
\hline
\end{tabular}

Mean $=6 S D=1$.

Table 4 revealed that out of the total rural women, 25 percent had small size families (up to 5 members), whereas 50 percent had medium-size families (6 to 8 members) and 35 percent had the large size of the family has more than 8 members.

This shows that a higher percentage (50\%) of rural women had a small family size having up to 5 members. The findings are in line with the findings of Garg (2010) and Deshmukh (2010).

Table 5: Distribution of Rural women according to type of family $(\mathrm{n}=100)$

\begin{tabular}{llll}
\hline $\begin{array}{l}\text { Sl. } \\
\text { No. }\end{array}$ & Family Type & $\begin{array}{l}\text { No. of } \\
\text { Beneficiaries }\end{array}$ & Percentage \\
\hline 1 & $\begin{array}{l}\text { Nuclear Family (3 to } 4 \\
\text { members) }\end{array}$ & 55 & 55 \\
2 & $\begin{array}{l}\text { Joint family (Above } 4 \\
\text { members) }\end{array}$ & 45 & 45 \\
\hline Total & $\mathbf{1 0 0}$ & $\mathbf{1 0 0}$ \\
\hline
\end{tabular}

Table 5 revealed that out of the total rural women, 55 percent had a nuclear family, and 45 percent had, joint family.

Thus, it can be concluded that the majority (55\%) of rural women had a nuclear family system. The findings are in line with the findings of Bhadauria (1996), Sheela et al. (1997), and Sharma et al. (2005).

Table 6 revealed that out of total rural women, 45.00 percent were doing agriculture, 35.00 percent beneficiaries were having engaged in agriculture + caste, whereas only 20.00 percent were having agriculture + laborer.

Table 6: Distribution of rural women according to their occupation

\begin{tabular}{llll}
\hline $\begin{array}{l}\text { S1. } \\
\text { No. }\end{array}$ & Occupation & $\begin{array}{l}\text { No. of } \\
\text { Beneficiaries }\end{array}$ & Percentage \\
\hline 1 & Agriculture & 45 & 45 \\
2 & Agriculture + Caste & 35 & 35 \\
3 & Agriculture + labour & 20 & 20 \\
\hline & Total & $\mathbf{1 0 0}$ & $\mathbf{1 0 0}$ \\
\hline
\end{tabular}

Thus, it is evident that a higher percentage $(45.00 \%)$ of rural women worked in agriculture. The findings align with Sharma et al. (2005) and Choudhury (2010).

Table 7: Distribution of Rural women according to their annual income

\begin{tabular}{llll}
\hline S1. No. & Annual Income & $\begin{array}{l}\text { No. of } \\
\text { Beneficiaries }\end{array}$ & Percentage \\
\hline 1 & Upto ₹ 15000/- & 20 & 20 \\
2 & ₹ 15001/- to 20,000/- & 45 & 45 \\
3 & ₹ 20001/- to 25000/- & 35 & 35 \\
\hline & Total & $\mathbf{1 0 0}$ & $\mathbf{1 0 0}$ \\
\hline
\end{tabular}

In Table No. 7, data reveals that out of total beneficiaries, 20.00 percent had an annual income up to 15,000 , and 45.00 percent had an annual income between ₹ 15,001/to 20,000 , whereas 35 percent had up to $25,000 /$ - level of income. Thus, it can be concluded that a higher percentage of the rural women $(45.00 \%)$ had annual income ₹ 15, 001 to 20,000/-. The findings are in line with the findings of Sharma (1997), Singh (2000), and Baghel (2003).

\section{Training Need of the Rural Women}

In the present study, the term 'training need' referred to the need to be minimized by imparting training towards participating in Income Generating Activities of rural women. The training need of rural women was the main focus of the present research work. Four aspects of training needs were selected to measure the extent of training needs of the rural women participating in income-generating activities of rural women. The total score of training needs could range from 0 to 60 . Based 
on their training need scores, the respondents were classified into three categories as shown in Table.

Table 8: Distribution of women according to their overall training needs $(\mathrm{n}=100)$

\begin{tabular}{llll}
\hline $\begin{array}{l}\text { S1. } \\
\text { No. }\end{array}$ & Level of Training Needs & $\begin{array}{l}\text { No. of } \\
\text { Beneficiaries }\end{array}$ & Percentage \\
\hline 1 & Less need (Upto 54 score) & 10 & 10 \\
2 & Medium need (55-82 score) & 20 & 20 \\
3 & High need (Above 82 score) & 70 & 70 \\
\hline & Total & $\mathbf{1 0 0}$ & $\mathbf{1 0 0}$ \\
\hline
\end{tabular}

Mean $=67 S D=13$.

Data presented in Table 8 show that the highest proportion $(70 \%)$ of the respondents had high training needs. In comparison, about $20 \%$ of them had medium training needs for income generation activities of rural women. The findings indicate that most of the respondents were in high need of training for their performance and participation in Income Generating Activities of rural women. This might be due to inadequate training offered by rural women to run the Income Generating Activities. Most of the respondents had short-term training experience, as stated earlier. The rural women in the study area had a desire to participate in income-generating activities. However, they could not do due to a lack of knowledge and sufficient information of the scheduled activities. Thus, the majority of the respondents fell in the high training need category.

The computed scores of training needs of all the aspects of training needs have been shown in Table 9. Data indicate that in all the components of training need, most of the respondents were in the high need category. This entails that rural women who wanted to

Table 9: Component-wise training needs of the rural women $(\mathrm{n}=100)$

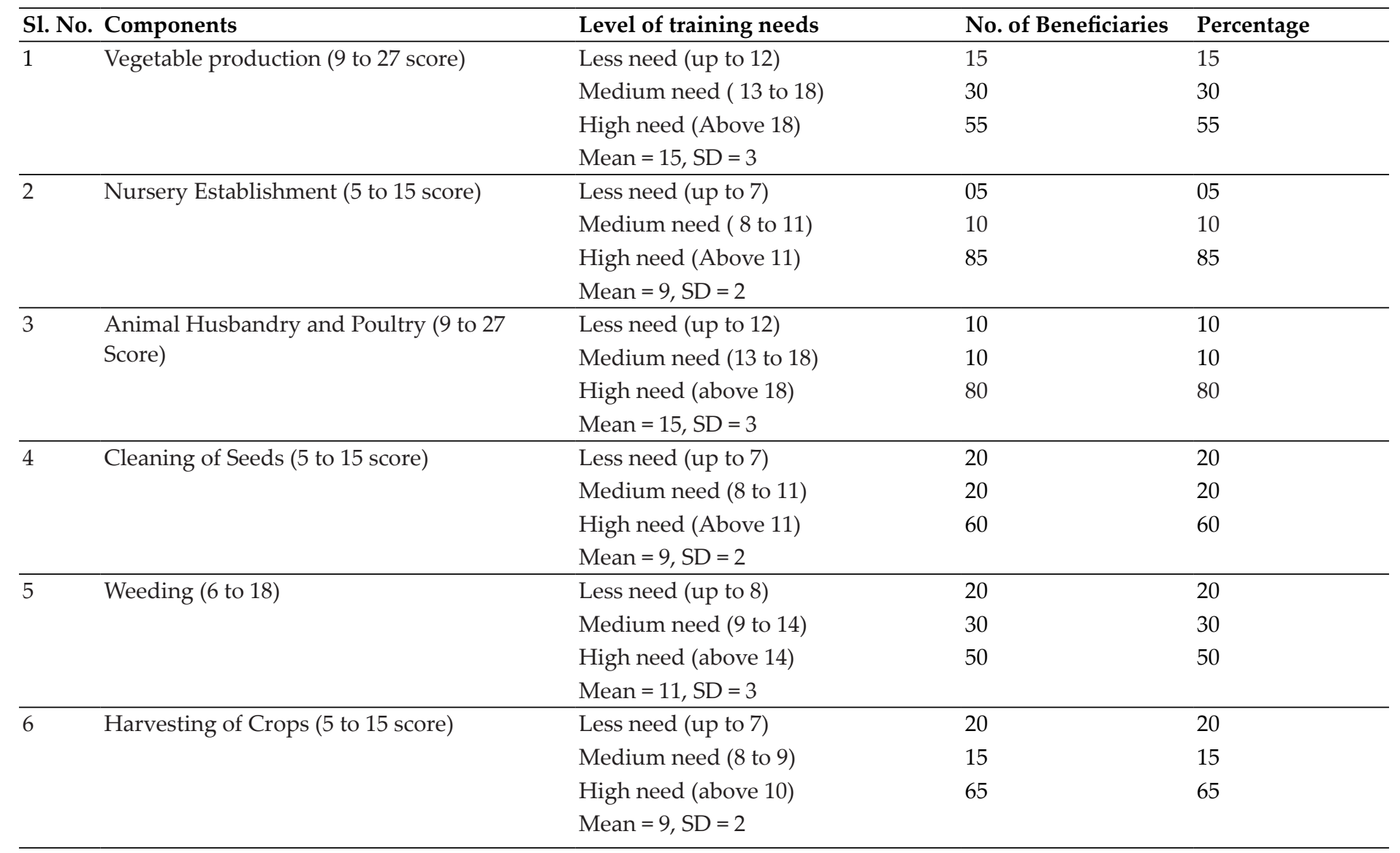


participate in homestead vegetable production, nursery establishment, livestock, poultry rearing, and cottage and handicraft production could not be involved due to lack of knowledge and skill. It indicates that they felt their training need very much in the above aspects of income generation.

Clearly expresses the percentage of training needs of different components in reference to the maximum possible scores of six components of training needs. Most of the $(85 \%)$ training needs were in nursery establishment. The rest three components, namely vegetable production and animal husbandry and poultry activities, claimed a more or less similar proportion of training needs. Based on this, it could be said that the rural women had the desire to participate in the cleaning of seeds may be due to a lack of homestead and farmland. To participate in other components, it would need some land for vegetables. However, still, the extent of training needs in vegetable production, nursery establishment, animal husbandry, and poultry was high. The findings are in line with the findings of Kandeeban and Velusamy (2016) and Singh and Mishra (2017).

\section{Relationships between the Selected Characteristics of the Rural Women and Their Extent of Training Needs}

The coefficient of Correlation ( $\mathrm{r}$ ) was computed in order to explore the relationships between the selected characteristics of the rural women and their extent of training needs in Income Generating Activities. Among the respondents' seven characteristics, only five, namely age, education, landholding, occupation, and income, showed a significant and positive relationship with their extent of training needs. However, the type of family of the respondents was negatively and significantly correlated with their extent of training needs. The rest of the characteristics viz. size of the family did not show any significant relationship with their extent of training needs.

The relationship between the type of the family and the extent of training need in conducting Income Generating Activities was significant and negative.
The relationship between age and extent of training needs in conducting Income Generating Activities was significant and followed a positive trend. It means that the increased the age of the respondents, the greater was their training need. Vegetable production, nursery establishment, and animal husbandry, and poultry rearing. When the farm size of the respondent's.

Table 10: Relationships between the selected characteristics of the rural women and their extent of training needs

\begin{tabular}{lll}
\hline S1. No. & $\begin{array}{l}\text { Characteristics (Independent } \\
\text { variables) }\end{array}$ & The ' $\mathbf{r}^{\prime}$ value \\
\hline 1 & Age & $0.209^{*}$ \\
2 & Education & $0.322^{*}$ \\
3 & Land holding & $0.352^{*}$ \\
4 & Size of family & 0.361 \\
5 & Type of The family & $-0.422^{* *}$ \\
6 & Occupation & $0.311^{*}$ \\
7 & Annual Income & $0.348^{* *}$ \\
\hline
\end{tabular}

** Significant at 0.01 level * Significant at 0.05 level.

In the relationship between education, landholding, occupation, and annual income and training needs of the respondents show a positive relationship. The findings are in line with the findings of Nashine et al. (2001), Chaitanyakumari (2003), Arularasan (2012) and Rokonuzzaman (2013).

\section{Suggestion for Improving the Income Generating Activities among Rural Women}

\section{Education can be used as a tool for empowerment of rural women}

Women's empowerment is not limited only to Indian society. If we deliberate the global aspect, we see that women are being given equal treatment in developed nations. If we recollect history, we come to know that women have always been given secondary positions in society. However, the difference between men and women created by Nature is but natural. Considering this background, we come to know that women's empowerment has now become a topic of the global discussion. Seeing all the aspects of this discussion, we will realize that education is the only means for women's 
empowerment. Therefore, literacy should spread amongst women. The literacy rate amongst the women in the post-independent Era is not as per the expectations. We, as a nation, dream of becoming a Super Power by 2020. For becoming a Super Power, each element of our society/ nation should contribute to thenation-building process. But women, who are a significant factor of this society, aren't literate then we can't expect to become a Super Power. Therefore, we must know the importance of women's education, which would, in turn, give motivation to women's empowerment. This paper aims to create awareness among women's about different empowerment and identifying the impact of education on women's overall empowerment.

\section{Awareness program should be arranged in villages on a regular basis}

Govt. of India has introduced various programmes under various sectors. The prime aim of these programs is the betterment of rural women and the alleviation of rural poverty. Various sectors recognized are housing, education, National Social Assistance Programme, sanitation, drinking water, and self-employment schemes etc.

\section{Easy access or route to finance should be provided}

Finance is at the core of the development process. Backed by solid empirical evidence, development practitioners are becoming increasingly convinced that efficient, wellfunctioning financial systems are crucial in channeling funds to the most productive uses and in allocating risks to those who can best bear them, thus boosting economic growth, improving opportunities and income distribution, and reducing poverty.

4. Proper allocation of government funds to needy individuals is the necessity of time since most of the talent died before coming to the picture due to lack of resources and help.

5. More schemes related to rural women's entrepreneurship could be of great help to empower and uplift the status of rural women in India.

\section{CONCLUSION}

Findings of the study may be concluded that age of respondents, level of education, source of income, and annual income were found significantly correlated to women empowerment. A person having a level of education, source of income, and annual income is likely to have higher empowerment. Education and occupation can bring desirable changes in human behavior, which ultimately helps in her empowerment. Income-generating experiences were found significantly correlated to empowerment, which means a person having higher income-generating experiences will have higher empowerment and vice versa. A person who used to have skill with income-generating through which s/ he can increase the income and can change his/her socio and economic empowerment status. Communication exposure was found to have a significant relationship with empowerment which indicates that a person with high communication exposure can changes his/ her empowerment. If a person can increase his/her communication exposure and involve himself/herself with different organizations, s/he will be able to changes his/her empowerment and strengthening their status.

\section{REFERENCES}

Ahirwal, P.K. 1999. An evaluation study of training of Rural youths for self-employment (TRYSEM) scheme of Hatta block of Damoh district (M.P.). M.Sc. (Ag) Thesis (unpublished), JNKVV, Jabalpur.

Arularasan, G.S. Swamy, B.K.N 2012. Factors contributing for the success of integrated tribal development programme in Western Ghats of South India. Mysore J. Agril. Sci., 46(1): 112115.

Aysha, A., Nobaya, A., Mohammad, A.I., Munira, W.J.W. and Dahlia, B.Z. 2018. Empowerment Scenario of Rural Women through Income Generating Activities in Bangladesh. Arts Social Sci. J., 9: 414.

Baba Z.A., Hakeem A.H., Ganai N.A., Malik K.M. and Sheikh T.A. 2009. Role of rural women in agriculture and income generating activities. Asian J. Home Sci., 4(1) : 1-3.

Baghel, S.P.K.S. 2003. A study on impact of Swarnjayanti Gram Swarojgar Yojna (SGSY) with special reference to credit utilization for minor irrigation among the tribal farmers of Dewsar block of Sidhi district (M.P.). M.Sc. (Ag.) Thesis (unpublished), JNKVV, Jabalpur. 


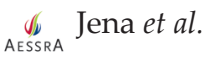

Bain, R.P. 2002. Impact of Barnenala National Watershed Development Programme on knowledge and adoption of watershead technology among beneficiaries of Sihora block of Jabalpur district. M.Sc. (Ag.) Thesis (unpublished), JNKVV, Jabalpur.

Batish, S., Kaur M. and Dhillon, M.K. 1997. Rural women: their role in economic development. In: G.S. Dhaliwal, N.S. Randhawa, Ramesh Arora and A.K. Dhawan (eds). Ecological Agriculture and Sustainable Development. Digigrafics, New Delhi, 2: 698-703.

Bhadouria, S.S. 1996. Attitude of beneficiaries towards IRDP in Marar Janpad, Gwalior district. M.Sc. (Ag.) Thesis (unpublished), JNKVV, Jabalpur.

Chaitanyakumari, M.S., Prabhakar, K. and Sasidhar, P.V.K. 2003. Impact of self employment programmes on income generation among tribal women - A case study from Andhra Pradesh. J. Res. ANGRAU., 31: 68-73.

Chari, T.V.R. 1983. Vistas employment for needy women and disabled. Soc. Welfare, 38(11): 14-16.

Choudhury, M.A. and Ali, M.D.H. 2010. Income, employment and consumption patterns of the tribal people in Manipur. J. Interacademicia, 14(4): 569-582.

Chouhan, H.S. 2003. A study on the effect of cotton production technology in term of adoption and production among the tribal farmers of Dhar district of M.P. M.Sc. (Ag.) Thesis (unpublished), JNKVV, Jabalpur.

Deshmukh, P.R. and Deshmukh, N.D. 2010. Availment of benefits of integrated rural development programme by beneficiaries. Agri. Update, 5(3/4): 409-411.

Dhawan, S., Rahgir, S.P. and Agrawal, S. 2002. Profile of rural women in ICDS Programme. Madhya. J. Extn. Edu., IV \& V(3): 66-67.

Govindappa, G.T. 1999. Rural women entrepreneurshipconstraints and strategies. Kurukshetra, 48(2): 11-14.

Gurjar, L.S. 2002. Role of elected representative in panchayati Raj System for agricultural development in Ghatigaon Janpad in Gwalior District (M.P.). M.Sc.(Ag.) thesis (unpublished) JNKVV. Jabalpur.

Hasan Shaikh Shamim, Hossain Moushumi Sultana, Sabina, Ghosh Mithun Kumar. 2015. Women's Involvement in Income Generating Activities and Their Opinion About Its Contribution: A Study of Gazipur District, Bangladesh. Science Innovation, 3(6): 72-80.

Kandeeban, M. and Velusamy, R. 2016. Training Needs of Rural Women in Hilly Areas for Their Empowerment. Soc. Sci. Rev., 2(2): 56-71.
Lyaqet, A. 2001. A study of the change in cropping pattern income and employment status among beneficiaries of National Watershed Development Project of Panagar block, Jabalpur district (M.P.). M.Sc. Thesis (unpublished), JNKVV, Jabalpur.

Mannan, M. 1992. Problems of Working Women in a City. Unpublished M.Sc. thesis, Punjab Agricultural University, Ludhiana, India.

Mehta, S. and Sethi, N. 1997. Targetting women for developing. Social Welfare, 43(10): 14-16.

Meshram, V. 2003. Impact of Swarnjayanti Gram Swarojgar Yojna with respect to credit utilization extended to beneficiaries for agricultures development in Mandla district (M.P.). M.Sc. (Ag.) Thesis (unpublished), JNKVV, Jabalpur.

Nashine, R. and Klrar, B.S. 2001. Empowering women through value addition techniques in fruit and vegetable. Indian J. Extn. Edu., 37: 32-33.

Patel, V.K.1999. Astudy on impact of integrated rural development programme (IRDP) on income and employment generation with reference to dairy enterprises in Rampur Naikin block of Sidhi district (M.P.). M.Sc. (Ag) Thesis (unpublished), JNKVV, Jabalpur.

Prajapati, I.B. 2006. A study on socio-economic factors responsible for technological gap of recommended wheat production technology among tribal farmers of Sidhi block of Sidhi district (M.P.). M.Sc. (Ag.) Thesis (unpublished), JNKVV, Jabalpur.

Ramu, G.N. 1989. Work and Marriage in Urban India - A Study of Dual and Single Eearner Couples. Sagi Publications, New Delhi.

Rokonuzzaman, M. 2013. Training needs of tribal people in carrying out income generating activities. Indian J. Extn. Edu., 13: $1,77-84$.

Sakhya, M.S. 2007. A study on adoption behavior of chickpea growers in Indor district, M.P. M.Sc. (Ag.) Thesis (unpublished) JNKVV, Jabalpur.

Sangwan, V., Singal, S. and Yadav, A. 1989. Constraints faced by rural women regarding participation in income generating activities. Indian J. Ext. Educ., 25(2): 81-84.

Sharma, N., Singh, U. and Jhanthani, A. 2005. Personal characteristics of agricultural labourers in Haryana state. Indian J. Extn. Edu., 5(2 \& 3): 116- 119.

Sharma, S.S. 1997. A study of profile characteristics enhancement in employment, crop yield and income of beneficiaries in watershed development project area of Jabalpur district, M.P. Ph.D. Thesis (unpublished), JNKVV, Jabalpur.

Sheela, S., Seema, B. and Shobhana, G. 1997. Analysis of socioeconomic profile of scheduled castes and families. Maha. J. Extn. Edu., 12: 204-206. 
Shendage, P.N., Jadhav, K.L. and Gaikwad, D.M. 2009. Employment, income and consumption pattern of tribals in Nashik. Maha. J. Agri. Sci., 5(3) 51.

Singh, J.P. 2000. Economic evaluation of Manchal watershed. National Institute of Agril. Extn. Mngt., Rajendra Nagar, Hyderabad-30.

Singh, M. 2003. Effectiveness of different communication channels on mustard growers of Mehgaon block of Bhind district (M.P.). M.Sc. (Ag.) Thesis (unpublished), JNKVV, Jabalpur.

Singh, O.R. 2001. Education and women's empowerment. Social Welfare, 48(1): 35-36.
Singh, S. and Mishra, O.P. 2017. Impact of income generating training programmes on knowledge gain by the rural women in Varanasi region. J. Pharmacogn. Phytochemi., SP1: 577-579.

Sudharani, K., Sreelatha Kishori, K. and Surendra, G. 2001. Empowerment of women in rural areas. Rural India, pp. 195198.

Sunitha, K. and Scallinguo, K. 2004. Collective Action for Poverty Alleviation and Women's Empowerment, National Food Policy Research Institute, May 2004.

Vergopoulos, K. 1978. “Capitalism and peasant productivity." J. Peasant Stud., 5(4): 446-465. 
